\title{
ГІСТОЛОГІЧНЕ ДОСЛІДЖЕННЯ ТОНКОЇ КИШКИ У ЩУРІВ ПРИ ЕКСПЕРИМЕНТАЛЬНОМУ МОДЕЛЮВАННІ ГОСТРОГО ПОШИРЕНОГО ПЕРИТОНІТУ НА ФОНІ СТРЕПТОЗОТОЦИНІНДУКОВАНОГО ЦУКРОВОГО ДІАБЕТУ
}

Гістологічне дослідження тонкої кишки у щурів при експериментальному моделюванні гострого поширеного перитоніту на фоні стрептозотоциніндукованого цукрового діабету

\section{Б. М. Вервега}

Львівський національний медичний університет імені Данила Галицького

Резюме. Актуальність гострого поширеного перитоніту (ГПП) на тлі цукрового діабету зумовлена поширеністю ендокринного захворювання та високими показниками летальності при видозміненому перебігу запального процесу очеревини в результаті гіперглікемії. Тяжкість перебігу даної поєднаної патології зумовлена прогресуванням ентеральної недостатносmі, яка супроводжується вираженими морорологічними змінами в стінці тонкої кишки, та є вхідними воротами для бактерійної контамінації.

Мета дослідження - вивчити морфоологічні зміни тонкої кишки в щурів у динаміці експериментального моделювання гострого поширеного перитоніту на фоноі стрептозотоциніндукованого цукрового діабету (СТД).

Матеріали і методи. В експерименті використано 48 білих щурів-самців. Цукровий діабет у дослідних тварин моделювали шляхом одноразового інтраперитонеального введення стрептозотоцину (Sigma) 3 розрахунку 60 мг/ке, ГПП - введенням 0,5 мл $10 \%$ профрільтрованої калової суспензії у черевну порожнину. Контрольну групу склали білі щури (n=8), яким підшкірно вводили фрізіологічний розчин 0,9\% NaCl (хлориду натрію). Проводили морфологічне дослідження тонкої кишки у тварин, виведених із експерименту на 1-шу, 3-ю та 7-му доби розвитку гострого запалення очеревини на фроні супутнього цукрового діабету.

Результати. Розвиток ГПП на тлі гіперглікемії характеризується виникненням дистрофрічних змін клітин слизової оболонки тонкої кишки, вираження яких зростає залежно від стадії розвитку перитоніту. Необхідно зазначити, що на 7-му добу експериментального моделювання даної поєднаної патології виявлено ознаки вакуольної дистрофрії міоцитів, що свідчить про розвиток патологічного процесу в усіх оболонках стінки. Тенденція до зниження фрункціональної активності слизової оболонки (зменшення товщини та зниження висоти ворсин й глибини крипт) простежується упродовж усіх (СБ. М. Вервега, 2021
ISSN 2706-6282(print) ISSN 2706-6290(online)

\begin{abstract}
Histological examination of the small intestine in rats in experimental modeling of acute generalized peritonitis against the background of streptozotocininduced diabetes mellitus
\end{abstract}

B. M. Verveha

Danylo Halytsky Lviv National Medical University e-mail: danaverveha@gmail.com

Summary. The topicality of acute generalized peritonitis (AGP) against the background of diabetes mellitus is due to the prevalence of endocrine disease and high mortality in the altered course of the inflammatory process of the peritoneum as a result of hyperglycemia. The severity of this combined pathology caused to the progression of enteral insufficiency, which is accompanied by pronounced morphological changes in the wall of the small intestine, and is the gateway to bacterial contamination.

The aim of the study - to research the morphological changes of the small intestine in the dynamics of experimental modeling of AGP against the background of streptozotocin (STZ)-induced diabetes.

Materials and Methods. The experiment was performed on 48 white male rats. Diabetes mellitus in experimental animals was simulated by a single intraperitoneal injection of streptozotocin (Sigma) at the dose of $60 \mathrm{mg} /$ $\mathrm{kg}$, AGP was simulated by injecting of $0.5 \mathrm{ml}$ of $10 \%$ filtered fecal suspension into the abdominal cavity. The control group consisted of white rats $(n=8)$, which were injected subcutaneously with saline $0.9 \% \mathrm{NaCl}$ (sodium chloride). A morphological study of the small intestine were performed on the first, third and seventh days of acute peritonitis on the background of concomitant diabetes mellitus.

Results. The development of AGP on the background of hyperglycemia is characterized by the appearance of dystrophic changes in the cells of the small intestinal mucosa, the severity of which increases depending on the stage of development of peritonitis. It should be noted that on the 7th day of experimental modeling of this combined pathology revealed signs of vacuolar dystrophy of the myocytes, which indicates the development of a pathological process in all layers of intestine. The tendency to decrease the functional activity of the mucous membrane (decrease in the thickness and decrease in the height of the villi and the depth of the crypts) is observed during all stages of acute peritonitis. Dystrophic changes of the epithelium 
стадій розвитку гострого запалення очеревини. Дистрофрічні зміни епітелію та м'язової оболонки, ексудативне запалення і порушення кровообігу створюють умови для порушення перистальтики й транслокаціі мікрофолори кишок у системний кровообіг.

Висновки. Перебіг ГПП на тлі СТД характеризується виникненням дистрофрічних змін клітин слизової та м'язової оболонок тонкої кишки. Зниження функціональної активності слизової оболонки тонкої кишки та прогресування в їі стінці альтеративно-ексудативних змін призводять до парезу кишок та подальшої транслокації патогенної мікрофрлори в системний кровообіг й черевну порожнину.

Ключові слова: гострий поширений перитоніт; стрептозотоциніндукований цукровий діабет; морфологічні зміни тонкої кишки.

\section{ВСТУП}

Лікування гострого поширеного перитоніту (ГПП) $€$ актуальною проблемою хірургії, що зумовлено летальністю при даному захворюванні, яка складає від 8,3 до 31,3 \% [1-6]. Підґрунтям тяжкого перебігу та високих показників смертності при гострому запаленні очеревини часто є супутня патологія серед котрої вагому частку займає цукровий діабет [7-13]. Гіперглікемія збільшує ріст та вірулентність мікроорганізмів, сприяє розвитку ендотоксемії унаслідок порушень мікробіоценозу кишок.

Згідно з сучасними уявлення, складовою виникнення синдрому ендогенної інтоксикації при абдомінальному інфікуванні $€$ гостра ентеральна недостатність, пусковим механізмом якої вважають порушення моторики кишок. Парез кишок і порушення пасажу хімусу призводять до трансформації умовно-патогенної мікрофрлори у патогенну та її подальшої транслокації.

В умовах поєднаної патології під впливом гіперглікемії змінена ініціальна нейтрофрільна відповідь призводить до атипового гіпергічного перебігу запального процесу очеревини, втрати бар'єрної функції кишок, їх морфологічної перебудови та проникнення мікроорганізмів у системний кровообіг й черевну порожнину.

Усе вищезгадане зумовлює актуальність поглибленого вивчення морфоструктурних змін тонкої кишки при поєднанні ГПП та цукрового діабету.

Метою дослідження було вивчити морфологічні зміни тонкої кишки в щурів у динаміці експериментального моделювання гострого поширеного перитоніту на тлі стрептозотоциніндукованого цукрового діабету (СТД).

\section{МАТЕРІАЛИ І МЕТОДИ}

Експериментальні дослідження проведено на 48 статевозрілих білих щурах-самцях масою тіла 180-225 г, яких утримували в умовах природної and muscular membrane, exudative inflammation and circulatory disorders create conditions for impaired peristalsis and translocation of intestinal microflora into the systemic circulation.

Conclusions. The course of AGP on the background of STZ-induced diabetes is characterized by the appearance of dystrophic changes in the cells of the mucosa and muscular layer of the small intestine. Decreased functional activity of the mucous membrane of the small intestine and the progression of alterative and exudative changes in its wall lead to intestinal paresis and subsequent translocation of pathogenic microflora into the systemic circulation and abdominal cavity.

Key words: acute generalized peritonitis; streptozotocininduced diabetes mellitus; morphological changes of the small intestine.

зміни режиму освітлення, температури та вологості повітря за стандартами віварію. Дослідження здійснено відповідно до положень Європейської конвенції про захист хребетних тварин, що використовують в експериментальних та інших наукових цілях (Страсбург, 1986); Директиви Ради Європи 86/609/EEC (1986 р.); Закону України № 3447 - IV «Про захист тварин від жорстокого поводження»; Загальних етичних принципів експериментів на тваринах, ухвалених Першим національним конгресом України з біоетики (2001р.).

Тварин поділили на дві групи. В основній групі тварин $(n=40)$ попередньо моделювали СТД та на 14 добу його розвитку 38 щурам ініціювали ГПП (у 2 тварин діабет не розвинувся). Вказану групу тварин поділили на підгрупи з метою вивчення морорологічних змін стінки товстої кишки в реактивній, токсемічній та термінальній стадії перитоніту (1; 3 та 7 доби від моменту введення калової суспензії). Контрольну групу склали білі щури (n=8), яким підшкірно вводили фрізіологічний розчин 0,9 \% $\mathrm{NaCl}$ (хлориду натрію).

Інсулінозалежну форму цукрового діабету відтворювали шляхом одноразового внутрішньочеревного введення натще стрептозотоцину (Sigma) в дозі 60 мг/кг, розчиненого в буфрерному натрієво-цитратному розчині (рH 4,5) [14]. Перед ін'єкцією тричі здійснювали обробку правої здухвинної ділянки 10 \% розчином бетадину. Голку вводили під кутом 45 до поверхні передньої черевної стінки до відчуття її «провалювання». Після ін'єкції тварини отримувала per os розчин глюкози протягом перших 24 год з метою запобігання транзиторної гіпоглікемії. Концентрацію глюкози натще визначали за допомогою портативного глюкометра (Accu-ChekActiveNew, Німеччина) шляхом нанесенням поверхневих насічок на кінчику хвоста у стерильних умовах.

ГПП моделювали шляхом введення пункційним способом у черевну порожнину щурів 10 \% профрільтрованої калової суспензії у дозі 0,5 мл на 
100 г маси тіла тварини не пізніше ніж через 20 хв після приготування [15]. Калову суспензію отримували, змішуючи ізотонічний розчин і вміст сліпої кишки трьох інтактних тварин, та двічі фрільтруючи іiї через подвійний шар марлі. Впродовж усього терміну моделювання поєднаної патології щурам вводили підшкірно інсулін від 2 до 5 разів на тиждень залежно від рівня глюкози в крові. Евтаназію тварин здійснювали шляхом декапітації під наркозом на 1-шу, 3-ю і 7-му доби перебігу гострого запалення очеревини на фоні цукрового діабету.

Для гістологічного дослідження забирали шматочки тонкої кишки, які фріксували у $10 \%$ розчині фрормальдегіду. В подальшому їх зневоднювали у спиртах зростальної концентрації, ортоксилолі, заливали у парафін і виготовляли зрізи. Отримані на санному мікротомі зрізи фрарбували гематоксиліном та еозином і вивчали структуру стінки тонкої кишки у нормі, а також характер морфологічних порушень при поєднаній патології. Мікроскопію і фротографрування гістологічних препаратів проводили за допомогою мікроскопа Nikon E200 з фротокамерою Nikon D5000 зі збільшеннями 100.

\section{РЕЗУЛЬТАТИ Й ОБГОВОРЕННЯ}

Результати гістологічного дослідження тонкої кишки щурів контрольної групи продемонстрували, що слизова, м'язова і серозна оболонки структурно розвинені, мають чіткі межі. Слизова оболонка містить ворсинки значної довжини, які виступають у просвіт кишки та крипти незначної глибини. В основній групі на 1 добу розвитку ГПП на тлі СТД виявлено незначне вкорочення та сплощення ворсинок слизової оболонки порівняно з контрольною. У певних ділянках ідентифіковано збільшені в розмірах клітини епітелію ворсин (за рахунок нерівномірної вакуолізації) із розмитими контурами. Секреторний апарат слизової оболонки тонкої кишки не зазнавав змін - у келихоподібних клітинах спостерігалося достатнє утворення слизу. Підслизовий шар - дещо розширений, містив незначний змішаноклітинний запальний інфрільтрат, в якому переважали лімороцити й моноцити, судини гіперемовані. Субсерозна жирова тканина містила дрібновогнищеві крововиливи, помірний змішаноклітинний запальний інфільтрат із локальним переважанням нейтрофрільних лейкоцитів (рис. 1).

На 3 добу розвитку даної поєднаної патології у тварин основної групи виявлено розширений просвіт тонкої кишки, заповнений кишковим вмістом. Висота та ширина ворсинок продовжували зменшуватися. Товщина слизової оболонки зменшена порівняно із 1 добою від моменту введення калової суспензії. Верифіковано дистрофрічні зміни, що проявлялися посиленою базофрільністю збільшених у розмірах клітин епітелію ворсин та їх нерівномірною вакуолізацією. Спостерігалися осередки десквамації епіте- лію. Характерна інсрільтрація слизової оболонки та підслизового шару нейтроорільними лейкоцитами, лімфоцитами, гістіоцитами і плазмоцитами (рис. 2). Набряк слизової оболонки супроводжувався збільшенням кількості набухлих келихоподібних екзокриноцитів. М'язовий шар витончений, містить мононуклеарний інорільтрат. Судини субсерозної жирової тканини гіперемовані. На очеревині - нашарування гомогенних та ниткоподібних оксисрільних мас, помірно виражена дифрузна інфрільтрація нейтрофрільними лейкоцитами, макрофагами, поодинокими плазматичними клітинами.

На 7-му добу розвитку даної поєднаної патології встановлено порушення міжклітинних зв'язків, масивну десквамацію епітелію. Контури клітин не чіткі, подекуди не візуалізується війчаста облямівка. Спостерігали виражені дистрофрічні зміни поверхневого епітелію, набряк пухкої сполучної тканини власної пластинки слизової оболонки. Визначається зменшення товщини ворсин і глибини крипт, посилена інфрільтрація слизової

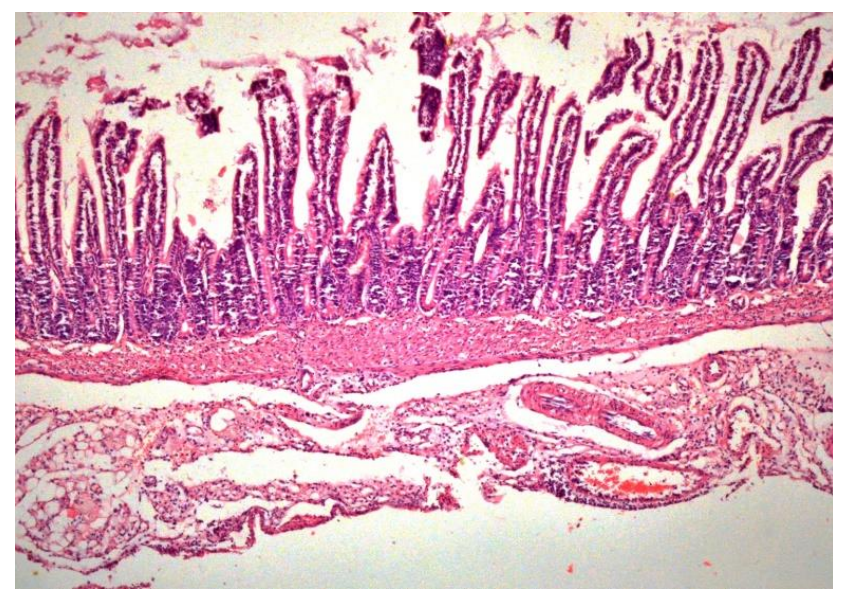

Рис. 1. Структура відділу тонкої кишки тварини на 1 добу гострого поширеного перитоніту на тлі цукрового діабету. Забарвлення гематоксиліном та еозином. $\times 100$

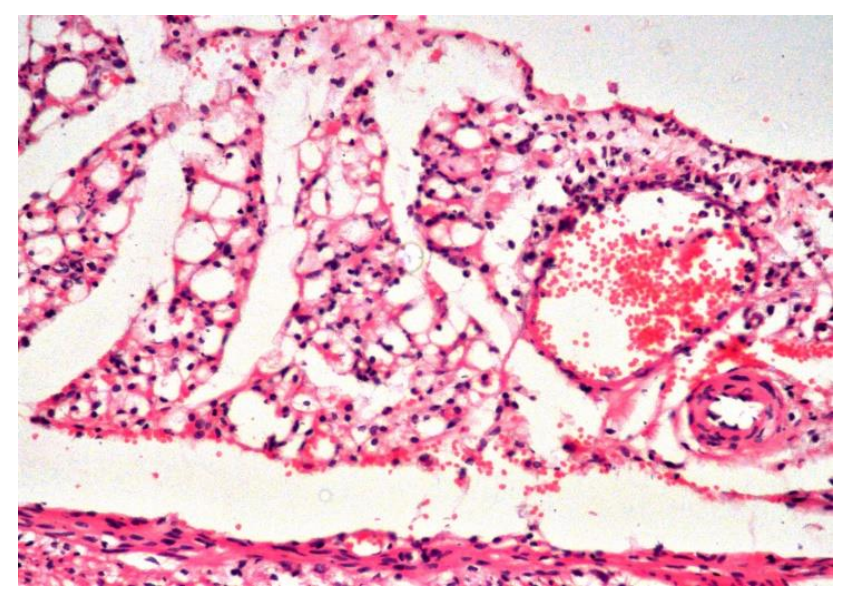

Рис. 2. Морфологічна картина стінки тонкої кишки тварини на 3-ю добу розвитку гострого поширеного перитоніту на тлі цукрового діабету. Забарвлення гематоксиліном та еозином. ×100.
Вісник медичних і біологічних досліджень Bulletin of Medical and Biological Research
$2(8), 2021$ 
оболонки й підслизового шару нейтрофрільними лейкоцитами, лімфоцитами, гістіоцитами та плазматичними клітинами (рис. 3). М'язова оболонка витончена, містить інорільтрат із локальним переважанням нейтрофрільних лейкоцитів, гладком'язові клітини зовнішнього шару мають ознаки вакуольної дистрофрії. Судини субсерозної жирової тканини гіперемовані.

Отримані результати дослідження свідчать, що розвиток ГПП на тлі гіперглікемії характеризується виникненням дистрофрічних змін клітин слизової оболонки тонкої кишки, вираження яких зростає залежно від стадії розвитку перитоніту. Необхідно зазначити, що на 7-му добу експериментального моделювання даної поєднаної патології виявлено ознаки вакуольної дистрофії міоцитів, що свідчить про розвиток патологічного процесу в усіх оболонках стінки. Поступове зниження фрункціональної активності слизової оболонки проявляється зменшенням товщини та зниженням висоти ворсин. Підтвердженням гіпергічного перебігу запалення очеревини на фоні цукрового діабету $є$ виражена інфрільтрація слизової оболонки, підслизового шару та м'язової оболонки моноцитами та лімфоцитами. Дистрофрічні зміни епітелію та м'язової оболонки, ексудативне запалення і порушення кровообігу створюють умови для порушення перистальтики й транслокації мікроорлори кишок у системний кровообіг.

\section{СПИСОК ЛІТЕРАТУРИ}

1. Etiology, treatment outcome and prognostic factors among patients with secondary peritonitis at Bugando Medical Centre, Mwanza, Tanzania / A. Mabewa, J. Seni, P. L. Chalya [et al.] // World Journal of Emergency Surgery. - 2015. - No. 10. - P. 47

2. Base excess and $\mathrm{pH}$ as predictors of outcomes in secondary peritonitis in a resource limited setting - A prospective study / O. O. Afuwape, O. Ayandipo, S. Aroso // Journal of Clinical Sciences. - 2020. - Vol. 17 (4). - P. 145-149.

3. The delta neutrophil indexis a prognostic factor for postoperative mortality in patients with sepsis caused by peritonitis / J. W. Kim, J. H. Park, D. J. Kim [et al.] // PLOS One. - 2017. - Vol. 12 (8). - P. e0182325.

4. Комплексный подход к коррекции энтеральной недостаточности в раннем послеоперационном периоде / А. П. Власов, Э. К. Салахов, В. А. Шибитов [и др.] // Хирургия. - 2016. - № 5. - С. 52-58.

5. Risk factors for mortality in postoperative peritonitis in critically ill patients / Y. Launey, B. Duteurtre, R. Larmet [et al.] // World J. Crit. Care Med. - 2017. - Vol. 6 (1). - P. 48-55.

6. Prasad N. B. G. A study of acute peritonitis: evaluation of its mortality and morbidity / N. B. G. Prasad, K. V. B. Reddy // International Surgery Journal. - 2016. Vol. 3 (2). - P. 663-668.

7. Comparison of peritoneal lavage with normal saline and normal saline plus antibiotic in acute peritonitis / M. Raeeszadeh, S. M. J. Hosseini, M. T. Khanmohammadi [et al.] // Trauma Monthly. - 2017. - Vol. 22 (5). - P. e58188.

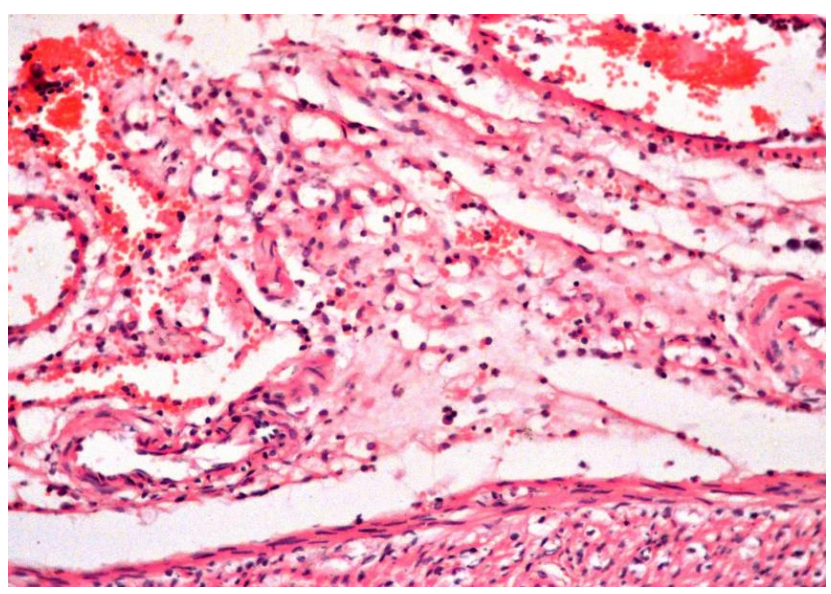

Рис. 3. Морфологічна картина стінки тонкої кишки тварини на 7-му добу розвитку гострого поширеного перитоніту на тлі цукрового діабету. Забарвлення гематоксиліном та еозином. ×100.

\section{ВИСНОВКИ}

1. Перебіг ГПП на тлі СТД характеризується виникненням дистрофрічних змін клітин слизової та м'язової оболонок тонкої кишки.

2. Зниження функціональної активності слизової оболонки тонкої кишки (зменшення товщини, зниження висоти ворсин і глибини крипт) та прогресування в її стінці альтеративно-ексудативних змін призводять до парезу кишок та подальшої транслокації патогенної мікрофрлори в системний кровообіг й черевну порожнину.

8. Multicenter study evaluating the role of Enterococci in secondary bacterial peritonitis / E. Cercenado, L. Torroba, R. Cantón [et al.] // Journal of Clinical Microbiology. - 2010. - Vol. 48 (2). - P. 456-459.

9. Patients with faecal peritonitis admitted to European intensive care units: an epidemiological survey of the GenOSept cohort / A. Tridente, G. M. Clarke, A. Walden [et al.] // Intensive Care Medicine. - 2014. - Vol. 40 (2). - 202-210.

10. Ross J.T. Secondary peritonitis: principles of diagnosis and intervention / J. T. Ross, M. A. Matthay, H. W. Harris // British Medical Journal. - 2018. - Vol. 361. - P. k1407.

11. Комплексна діагностика гострого гнійного перитоніту у хворих з атиповою клінічною картиною / Є. Д. Хворостов, Ю. Б. Захарченко, М. С. Томін [ та ін.] // Науковий вісник Ужгородського університету, серія «Медицина». - 2011. - Вип. 2 (41). - С. 265-267.

12. Чурпій І. К. Прогнозування перебігу хірургічного лікування дифузного перитоніту з урахуванням кількісної оцінки фракторів ризику / І. К. Чупрій // Медична інформатика та інженерія . - 2011. - № 4. - С. 50-57.

13. Risk factors for early-onset peritonitis in Southern Chinese peritoneal dialysis patients / H. Wu, R. Huang, Yi Chunyan [et al.] // Peritoneal Dialysis International. - 2016. - Vol. 36 (6). - P. 640-646.

14. Ramos-Lobo A. M. Streptozotocin-induced diabetes disrupts the body temperature daily rhythm in rats / A. M Ramos-Lobo, D. C. Buonfiglio, J. Cipolla-Neto // Diabetology \& Metabolic Syndrome. - 2015. - No. 7. - P. 39. 
15. Экспериментальная модель распространенного калового перитонита / В. А. Лазаренко, В. А. Липатов, Ю. Ю. Блинков, Д. В. Скориков // Курский научно-прак-

\section{REFERENCES}

1. Mabewa A, Seni J, Chalya PL, Mshana SE, Gilyoma JM. Etiology, treatment outcome and prognostic factors among patients with secondary peritonitis at Bugando Medical Centre, Mwanza, Tanzania. World Journal of Emergency Surgery. 2015;10: 47. DOI: 10.1186/s13017-015-0042-5

2. Afuwape OO, Ayandipo O, Aroso S. Base excess and $\mathrm{pH}$ as predictors of outcomes in secondary peritonitis in a resource limited setting - A prospective study. Journal of Clinical Sciences. 2020;17(4): 145-149. DOI: 10.4103/jcls.jcls_18_20

3. Kim JW, Park JH, Kim DJ, Choi WH, Cheong JC, Kim JY. The delta neutrophil indexis a prognostic factor for postoperative mortality in patients with sepsis caused by peritonitis. PLOS One. 2017;12(8): e0182325. DOI: 10.1371/ journal.pone.0182325

4. Vlasov AP, Salakhov EK, Shibitov VA, Vlasov PA, Bolotskikh VA. [Integrated approach to correction enteral insufficiency in early postoperative period]. Khirurgiya. 2016;5: 52-8. Russian. DOI: 10.17116/hirurgia2016552-58

5. Launey Y, Duteurtre B, Larmet R, Nicolas N, Tawa A, Mallédant $Y$, et al. Risk factors for mortality in postoperative peritonitis in critically ill patients. World J Crit Care Med. 2017;6(1): 48-55. DOI:10.5492/wjccm.v6.i1.48

6. Prasad NBG, Reddy KVB. A study of acute peritonitis: evaluation of its mortality and morbidity. International Surgery Journal. 2016;3(2): 663-8. DOI:10.18203/2349-2902. ISJ20161140

7. Raeeszadeh M, Hosseini SMJ, Khanmohammadi MT, Manoochehry S, Rasouli H.R. Comparison of peritoneal lavage with normal saline and normal saline plus antibiotic in acute peritonitis. Trauma Monthly. 2017;22(5): e58188. DOI: 10.5812/traumamon.58188 тический вестник «Человек и его здоровье». - 2008. № 4. - Р. 128-132.

8. Cercenado E, Torroba L, Cantón R, Martínez-Martínez L, Chaves F, García-Rodríguez JA, et al. Multicenter study evaluating the role of Enterococci in secondary bacterial peritonitis. Journal of Clinical Microbiology. 2010;48(2): 4569. DOI: 10.1128/JCM.01782-09

9. Tridente A, Clarke GM, Walden A, McKechnie S, Hutton $P$, Mills $G H$, et al. Patients with faecal peritonitis admitted to European intensive care units: an epidemiological survey of the GenOSept cohort. Intensive Care Medicine. 2014;40(2): 202-10. DOI: 10.1007/s00134-013-3158-7

10. Ross JT, Matthay MA, Harris HW. Secondary peritonitis: principles of diagnosis and intervention. British Medical Journal. 2018;361: k1407. DOI:10.1136/bmj.k1407

11. Khvorostov YeD, Zakharchenko YuB, Tomin MS, Morozov SO. [Complex diagnostics of acute purulent peritonitis in patients with atypical clinical manifestation]. Naukovyi visnyk Uzhhorodskoho universytetu, seriia «Medytsyna». 2011;2(41): 265-7. Ukrainian.

12. Churpii IK. [Prediction of surgical treatment with pour peritonitis quantifying risk factors]. Medychna informatyka ta inzheneriia. 2011;4: 50-7. Ukrainian.

13. Wu H, Huang R, Chunyan Yi, Wu J, Guo Q, Zhou Q, et al. Risk factors for early-onset peritonitis in Southern Chinese peritoneal dialysis patients. Perit Dial Int. 2016;36(6): 640-6. DOI:10.3747/pdi.2015.00203

14. Ramos-Lobo AM, Buonfiglio DC, Cipolla-Neto J. Streptozotocin-induced diabetes disrupts the body temperature daily rhythm in rats. Diabetology \& Metabolic Syndrome. 2015;7: 39. DOI: 10.1186/s13098-015-0035-2

15. Lazarenko VA, Lipatov VA, Blinkov YuYu, Skorikov DV. [Experimental model of diffuse fecal peritonitis]. Kurskiy nauchno-prakticheskiy vestnik "Chelovek i ego zdorovye". 2008;4: 128-32. Russian. 